Jurnal Hukum Mimbar Justitia

Fakultas Hukum Universitas Suryakancana

Vol. 6 No. 1 - Juni 2020, hlm. 90-101.

ISSN: 2477-5681 (Cetak), ISSN: 2580-0906 (Online)

Open Access at: https://jurnal.unsur.ac.id/jmj

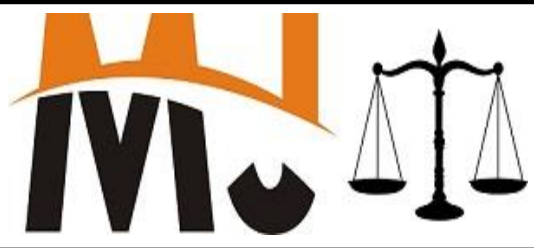

\title{
KORBAN TINDAK PIDANA PEMERKOSAAN DALAM PERSPEKTIF VIKTIMOLOGI
}

Budi Heryanto

Sekolah Tinggi Hukum Pasundan Sukabumi

Email: budiheryanto45@gmail.com

Andi Maulana

Universitas Suryakancana

Email: andimaulana@gmail.com

Annisa Adha Azzahra

Universitas Suryakancana

Email: adhaazzahraannisa@gmail.com

Marina Safira Sopiana

Universitas Suryakancana

Email: marinasafirasopiana@gmail.com

Sri Diyantie

Universitas Suryakancana

Email: sridiyantie@gmail.com
Riska Anggraeni

Universitas Suryakancana

Email: riskaanggraeni054@gmail.com

Ashraf Firmansyah

Universitas Suryakancana

Email: ashraffirmansyah3@gmail.com

Dea Natali Christy

Universitas Suryakancana

Email: deanatalichristy@gmail.com

Sopi Salma Sopia

Universitas Suryakancana

Email: sopisalmasopia18@gmail.com

Putri Alya Yuliani

Universitas Suryakancana

Email: ptrialya01@gmail.com

\section{ABSTRAK}

Kejahatan pemerkosaan menjadi ancaman serius yang menimpa perempuan oleh pelaku kejahatan yang menimbulkan keresahan di masyarakat. Tidak jarang yang menjadi korban kejahatan perkosaan adalah anak di bawah umur. Perempuan yang seharusnya mendapat perlindungan dari segala bentuk ancaman ternyata belum terwujud dalam prakteknya. Hukum positif Indonesia yang lebih fokus kepada pelaku tindak pidana dibanding dengan memperhatikan korban. Sejumlah peraturan lain pada saat penanganan kejahatan sejak penyelidikan, penyidikan, penuntutan, praperadilan dan pelaksanaan hukum, saksi dan korban kurang diperhatikan. Dampak yang sulit disembuhkan bagi korban pemerkosaan berupa sakitnya mental dan psikis menjadi perhatian bagi korban pemerkosaan. Tidak jarang kejahatan yang berkenaan dengan diri perempuan ini tidak tersentuh oleh penegakan hukum. Hal-hal yang menyababkan mengapa kejahatan kepada perempuan dapat terjadi dan mengapa tidak sedikit kasus pemerkosaan tidak diselesaikan secara hukum akan dibahas dalam penelitian ini.

Kata Kunci : Korban, Pemerkosaan, Tindak Pidana, Viktimologi 
Budi Heryanto dkk

Jurnal Hukum Mimbar Justitia

Vol. 6 No. 1 - Juni 2020

\section{ABSTRACT}

The crime of rape is a serious threat to women by criminals that cause unrest in society. It is not uncommon for minors to become victims of the crime of rape. Women who should receive protection from all forms of threats have not yet materialized in practice. Indonesian positive law is more focused on the perpetrators of criminal acts than on victims. Many other regulations on the handling of crimes since investigation, investigation, prosecution, pretrial and law enforcement, witnesses, and victims have received little attention. The impact that is difficult to cure for rape victims in the form of mental and psychological illnesses is a concern for rape victims. It is not uncommon for crimes related to women to be left untouched by law enforcement. The reasons why crimes against women can occur and why many rape cases are not legally resolved will be discussed in this study.

Keywords : Victims, Rape, Crime, Victimology

\section{PENDAHULUAN}

Kejahatan terhadap perempuan dan anak di bawah umur sekarang ini menjadi perhatian dikarenakan kejahatan perilaku pelaku laki-laki yang amoral. ${ }^{1}$ Tidak jarang pada proses penyelesaiannya menimbulkan kesulitan, baik pada tahap penyidikan, putusan dan pasca pengadilan. Yang pertama pada tahap pelaporan, korban dengan penderitaan fisik dan psikis, harus dapat menceritakan apa yang telah menimpa dirinya. Kedua, korban mesti hadir dalam persidangan dengan segala biaya sendiri dalam keadaan

1 Zuleha, 2015, Perlindungan Hukum Terhadap Anak Korban Pemerkosaan Dalam Perspektif Viktimologi, Jurnal Hukum Samudra Keadilan, Vol. 10, No. 01, Edisi Januari-Juli, Fakultas Hukum Universitas Samudra, Aceh, hlm. 126. mental dan psikis yang terganggu. Ketiga, korban mendapat labelisasi buruk atas dirinya dari lingkungan bahkan tidak diterima dikeluarganya, dan yang utamanya korban tidak mendapat ganti rugi dari siapapun. Selain kesulitan dalam batasan di atas, juga kesulitan pembuktian pemerkosaan atau perbuatan cabul yang umumnya dilakukan tanpa kehadiran orang lain. ${ }^{2}$

Kejahatan pemerkosaan umumnya pada perempuan dewasa namun tidak jarang teradapat kasus pemerkosaan terhadap anak di bawah umur. Kejahatan pemerkosaan sangat berdampak pada psikologi korban,

\begin{tabular}{llr}
\hline 2 Leden Marpaung, 1996, & Kejahatan \\
Terhadap Kesusilaan Dan & Masalah \\
Prevensinya, Sinar Grafika, Jakarta, hlm. 81.
\end{tabular}


Budi Heryanto dkk

Jurnal Hukum Mimbar Justitia

Vol. 6 No. 1 - Juni 2020

apalagi korban adalah anak yang akan memberikan dampak trauma berkepanjangan dan yang lebih miris lagi adalah anak korban pemerkosaan yang setelah dewasanya bekerja sebagai pekerja seks komersial. Dengan membicarakan pelacuran sama artinya membicarakan persoalan klasik dan kuno. Tetapi karena kebutuhan untuk menyelesaikanya, maka selalu menjadi relevan dengan setiap perkembangan manusia dimanapun. Menurut Kartono, pelacuran atau yang sering disebut dengan prostitusi atau pemuas nafsu seks, merupakan jenis pekerjaan yang setua umur manusia itu sendiri. ${ }^{3}$

Tindak pidana pemerkosaan tidak hanya terjadi di daerah kota besar dengan tingkat kriminalitas tinggi dan kesadaran atau pengetahuan hukumnya, tapi juga terjadi di pedesaan yang relatif masih memegang nilai tradisi dan adat istiadat. ${ }^{4}$

3 Mia Amalia, 2016, Analisis Terhadap Tindak Pidana Prostitusi Dihubungkan Dengan Etika Moral Serta Upaya Penanggulangan Di Kawasan Cisarua Kampung Arab, Jurnal Hukum Mimbar Justitia, Vol. 02, No. 02, Edisi Juli-Desember, Fakultas Hukum Universitas Surrakancana, Cianjur, hlm. 862.

4 Ira Dwiati, 2007, Perlindungan Hukum Terhadap Korban Tindak Pidana Perkosaan Dalam Peradilan Pidana, Tesis Fakultas
Fenomena ini menunjukan bahwa tindak pidana pemerkosaan adalah masalah serius bagi setiap sudut kehidupan masyarakat Indonesia.

Tidak jarang peristiwa pemerkosaan tidak dilaporkan kepada aparat polisi. Alasan kasus-kasus perkosaan tidak dilaporkan oleh korban kepada aparat penegak hukum untuk diproses ke Pengadilan karena beberapa faktor, diantaranya korban merasa malu dan tidak ingin aib yang menimpa dirinya diketahui oleh orang lain atau korban merasa takut karena telah diancam oleh pelaku bahwa dirinya akan dibunuh jika melaporkan kejadian tersebut kepada polisi. Hal ini tentu saja mempengaruhi perkembangan mental/kejiwaan dari para korban dan juga berpengaruh pada proses penegakan hukum itu sendiri untuk mewujudkan rasa keadilan bagi korban dan masyarakat. ${ }^{5}$

Anak merupakan kelompok yang lemah dan rentan sehingga memerlukan perlindungan agar hak-

Hukum, Universitas Diponogoro, Semarang, hlm.1.

Barda Nawawi, 2002, Bunga Rampai Kebijakan Hukum Pidana, Citra Aditya Bakti, Bandung, hlm. 1-2. 


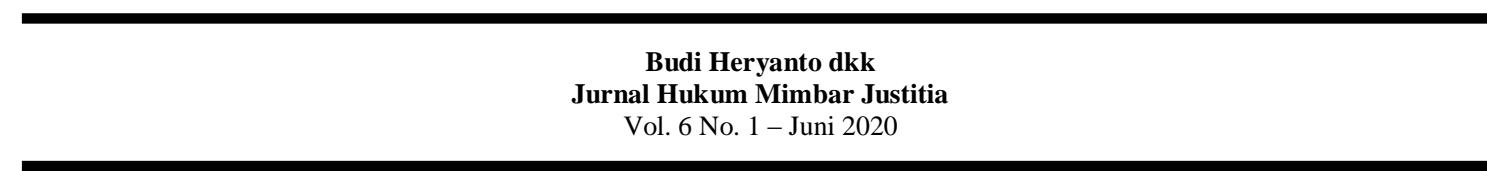

haknya dapat terpenuhi. Perlindungan terhadap anak Indonesia bertujuan agar anak dapat tumbuh dan berkembang secara optimal. Tantangan perlindungan anak di Indonesia adalah dengan mewujudkan pemenuhan hak anak namun sekaligus dalam waktu yang bersamaan mampu memberikan perlindungan kepada anak dari bahaya yang menintai mereka, yang pada akhirnya dapat menjauhkan anak dari ancaman perampasan hak anak. ${ }^{6}$ Ketentuan ini juga semestinya berlaku bagi perempuan dewasa yang mereka sama-sama harus dilindungi keberadaannya dari oknum laki-laki yang melakukan tindak pidana.

\section{METODE PENELITIAN}

Metode penelitian yang akan digunakan di dalam penelitian karya ini adalah metode pendekatan Yuridis Normatif yang menggunakan konsep, aturan dan norma sebagai refleksi kehidupan di masyarakat yang

6 Trini Handayani, 2016, Perlindungan Penegakan Hukum Terhadap kasus Kekerasan Seksual Pada Anak, Jurnal Mimbar Justitia Vol. II No. 02, Edisi JuliDesember, Fakultas Hukum Universitas Suryakancana, Cianjur, hlm. 826. berkaitan dengan penelitian ini. Bahan penelitian yang digunakan adalah bahan sekunder dengan menggunakan buku-buku, karya ilmiah dan internet. Semua bahan penelitian yang berkaitan dengan karya ini dipelajari kemudian ditulis dengan metode deskriptif analitis yang kemudian ditarik simpulan dan saran pada penelitian Tindak Pidana Pemerkosaan Dalam Perspektif Viktimologi.

Permasalahan muncul dari penelitian tentang Tindak Pidana Pemerkosaan Dalam Perspektif Viktimologi seperti alasan mengapa korban kejahatan pemerkosaan tidak melaporkan kejahatan kepada polisi hingga dimana dan bagaimana korban tindak pidana pemerkosaan mendapat perlindungan.

\section{PEMBAHASAN}

Dalam Undang-Undang Nomor 31 Tahun 2014 perubahan atas UndangUndang Nomor 13 Tahun 2006 Tentang Perindungan Saksi dan Korban Pasal 1(satu) Ayat 3 (tiga), korban adalah orang yang mengalami penderitaan fisik, mental, dan/atau kerugian 
Budi Heryanto dkk

Jurnal Hukum Mimbar Justitia

Vol. 6 No. 1 - Juni 2020

ekonomi yang diakibatkan oleh suatu tindak pidana. Selanjutnya, Declaration of Basic Principles of Justice for Victims of Crime and Abuses of Power, mendefinisikan korban kejahatan sebagai orang yang secara perseorangan atau bersama-sama, menderita kerugian, termasuk kerugian fisik atau mental, penderitaan emosional, kerugian ekonomis atau pelemahan substansial dari hak-hak dasar mereka, melalui tindakan atau kelalaian yang merupakan pelanggaran terhadap hukum yang berlaku di negara-negara anggota termasuk hukum-hukum yang melarang penyalahgunaan kekuasaan yang bersifat pidana.

Peran korban sebagai Participating Victims biasanya terjadi akibat kurangnya kesadaaran dari korban untuk lebih berhati-hati. Viktimisasi tidak selalu murni berasal dari pelaku semata, melainkan korban juga dapat ambil bagian sebagai pelaku dari kejahatan itu sendiri. Mendelson berpendapat, korban dapat dibedakan menjadi 5 (lima) macam dengan berdasar pada derajat kesalahannya, yaitu: ${ }^{7}$ yang sama sekali tidak bersalah, yang menjadi korban karena kelalaiannya sendiri, yang sama bersalahnya dengan pelaku, yang lebih bersalah daripada pelaku, dan korban adalah satu-satunya yang bersalah.

Tindak pemerkosaan yang marak terjadi dimasa sekarang ini bukanlah masalah yang baru muncul kepermukaan. Perempuan sebagai orang yang dirugikan dimana pelaku dalam melakukan aksinya, melakukan pula ancaman kekerasan yang diutarakan kepada korban, baik ancaman akan dibunuh jika melaporkan kejadian tersebut maupun ancaman diperkosa kembali. Bentuk ancaman ini menjadi beban selanjutnya yang korban dapatkan setelah sebelumnya pendapat perlakukan pemerkosaan. Hal ini yang kemudian menjadi penyebab mengapa tidak jarang korban kejahatan pemerkosaan tidak berani menceritakan apa yang telah menimpanya dan tidak melaporkan pelaku kejahatan pemerkosaan kepada polisi. Sehingga pelaku kejahatan pemerkosaan tidak dapat diproses dan

7 Ira Dwiati, 2007, Perlindungan Hukum Terhadap.......Op.Cit, hlm. 50. 


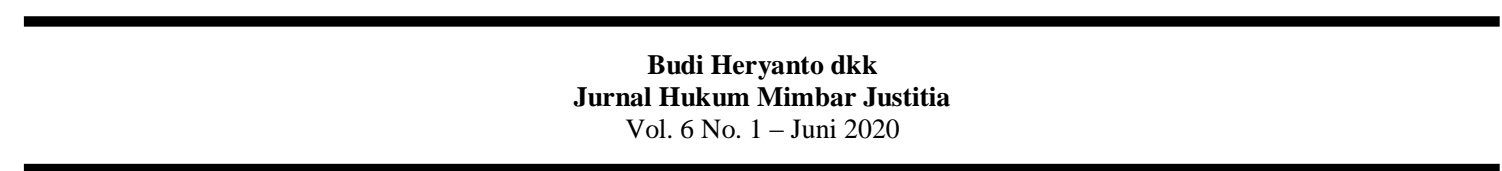

dengan leluasanya beraktivitas tanpa rasa khawatir bahkan hingga berulang kali melakukan kejahatan serupa.

Korban sebagai pihak yang paling dirugikan akibat peristiwa yang dialaminya, tidak mendapatkan perhatian yang sesuai. Kasus dalam peradilan seringkali menempatkan korban sebagai pihak yang terabaikan. Penderitaan mental dan psikis adalah akibat yang pasti timbul dari tindak pidana pemerkosaan. Apalagi korban pemerkosaan adalah anak di bawah umur yang akan sangat perpengaruh bagi kejiwaan dan masa depan anak. Anak-anak korban perkosaan (chield rape) adalah kelompok yang paling sulit pulih. Mereka cenderung akan menderita trauma akut. Masa depannya akan hancur, dan bagi yang tidak kuat menanggung beban, maka pilihan satu-satunya akan bunuh diri. Aib, perasaan merasa tercemar dan kejadian yang biadab itu akan terus menerus mengahantui korban, sehingga tidak jarang mereka memilih menempuh jalan pintas untuk melupakan serta mengakhiri semua penderitaannya. $^{8}$

Tidak jarang korban kejahatan pemerkosaan yang tidak melaporkan peristiwa yang menimpa dirinya diakibatkan beberapa pertimbangan seperti yang dijelaskan sebelumnya. Permasalahan yang dihadapi korban selanjutnya jika melaporkan kejadian pemerkosaan diantaranya sebagai berikut.

a. Saat melaporkan kejadian yang dialaminya kepada aparatur, korban pemerkosaan dengan keadaan trauma dan sakit psikisnya harus mengulangi kembali kisah berikut rekonstruksi aib perkosaan yang dialaminya.

b. Ancaman yang dilontarkan pelaku pemerkosaan kepada korban yang berupa ancaman pemerkosaan kembali dan ancaman dibunuhnya korban.

c. Dalam pelaksanaan persidangan, korban pemerkosaan hadir

8 Bagong Suyanto dan Emy Susanti Hendrarso, 1996, Wanita Dari Subordinasi dan Marginalisasi Menuju ke Pemberdayaan, Airlangga University Press, Surabaya, hlm.15. 
Budi Heryanto dkk

Jurnal Hukum Mimbar Justitia

Vol. 6 No. 1 - Juni 2020

kepersidangan dengan biaya

sendiri. Korban pemerkosaan

harus memberikan kesaksian dan mengulang cerita mengenai pengalaman pahitnya dan membuat rekonstruksi peristiwa perkosaan. Tekanan juga terjadi saat korban pemerkosaan dipertemukan dengan orang yang dibencinya (pelaku). Dan korban pemerkosaan dengan keadaan trauma harus berhadapan dengan pengacara pelaku pemerkosaan yang berusaha menghilangkan kesalahan pelaku.

d. Masa setelah persidangan, korban tindak pidana pemerkosaan tidak mendapatkan ganti rugi dari pihak manapun diperparah dengan labelisasi oleh masyarakat kepada korban pemerkosaan yang menyebabkan menambahnya tekanan psikis dari aibnya, tak jarang keluarga korban pemerkosaan tidak menerima korban pemerkosaan. ${ }^{9}$

Terungkapnya kejatan pidana pemerkosaan tidak luput dari peran korban dalam memberikan keterangan. Keberhasilan hukum dalam menindaklanjuti peristiwa hukum yang kuncinya adalah laporan dari pihak yang dirugikan dan atau Whisleblower. Dengan tidak adanya peran saksi atau korban, dapat dipastikan suatu peristiwa hukum menjadi Dark Number. Yang menjadi acuan dalam sistem hukum Indonesia adalah adanya saksi dalam suatu penyelesaian peristiwa hukum.

Meninjau akibat yang dialami korban tindak pidana pemerkosaan, adanya pendamping yang dilakukan oleh Dinas Sosial membantu korban tindak pidana pemerkosaan untuk memulihkan kondisi mental korban perlu ditingkatkan. Korban seperti halnya juga pelaku kejahatan dapat berupa perseorangan, kelompok dan masyarakat yang mendapat kerugian akibat perbuatan dari pelaku kejahatan. Kerugian yang diderita korban akan menimbulkan beban dan tekanan psikologis, seperti rasa kesal, jengkel, takut yang berkepanjangan trauma, stres atau bahkan gangguan kejiwaan.

9 Ira Dwiati, 2007, Perlindungan Hukum Terhadap........Loc.Cit,. 


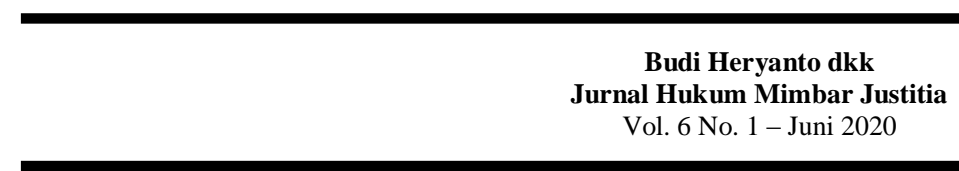

Pemenuhan keadilan bagi korban pemerkosaan tidak cukup dengan pemidanaan pelaku pemerkosaan, namun sampai dengan pulihnya kembali penderitaan yang dialami korban pemerkosaan dan penggantian kerugian yang dialami korban karena peristiwa pemerkosaan yang dialaminya membuat korban tidak dapat menjalankan kesehariannya dan harus memberikan kesaksian saat melaporkan dan pada saat menjalani proses persidangan, dimana korban dengan segala penderitaannya harus mengeluarkan biaya dalam menindaklanjuti kejahatan yang menimpanya. Hak korban pemerkosaan untuk mendapatkan ganti rugi dan rehabilitasi hingga benar-benar pulih dan kembalinya keadaan, baik dari pelaku pemerkosaan ataupun dari Negara. Hak tersebut mesti oleh korban dapatkan secara penuh. Peran keluarga dan masyarakat dalam memberi dukungan bagi korban pemerkosaan tidak merasa sendiri dalam mengahadapi peliknya kejahatan yang menimpanya.
Kurangnya perlindungan bagi saksi dan korban menjadi landasan lahirnya Undang-Undang Nomor 31 Tahun 2014 perubahan atas UndangUndang Nomor 13 Tahun 2006 Tentang Perindungan Saksi dan Korban. Pada UU tersebut diberikan hak-hak bagi saksi dan korban dalam Pasal 5 (lima) ayat 1 (satu) huruf a sampai p. Saksi dan korban tindak pidana tertentu mendapat perlindungan lebih bagi korban pelanggaran hak asasi manusia berat, korban tindak pidana terorisme, korban tindak pidana perdagangan orang, korban tindak pidana penyiksaan, tindak pidana kekerasan seksual dan korban penganiayaan berat. Dengan itu, keberadaan saksi dan korban lebih mendapat perlindungan yang Negara berikan. Ketentuan ini akan berlaku jika saksi dan/atau korban dapat melaporkan apa yang ia alami atau yang ia saksikan kepada pihak berwenang atau dengan kata lain peristiwa yang terjadi tidak hanya menjadi Dark Number semata tanpa kehadiran Negara untuk memberikan perlindungan dan 
Budi Heryanto dkk

Jurnal Hukum Mimbar Justitia

Vol. 6 No. 1 - Juni 2020

kepastian hukum atas Hak Asasi

Manusia yang dimiliki warganya.

Terdapat pula Peraturan

Pemerintah Nomor 2 Tahun 2002

tentang Tata Cara Perlindungan Korban

dan Saksi dalam Pelangaran HAM Berat

dan Undang-Undang Nomor 26 Tahun

2000 tentang Pengadilan Hak Asasi

Manusia. Ketiga aturan ini berkenaan dengan posisi, perlindungan dan cara memperlakukan saksi dan korban tindak pidana pemerkosaan yang tergolong pelanggaran HAM berat. Aturan yang telah disebutkan di atas sangat membutuhkan peran saksi dan/atau korban yang sangat penting bagi sistem hukum di Indonesia dalam upaya penyelesaian perkara kejahatan. Meskipun pada Pasal 5 (lima) ayat 1 huruf a uran Pemerintah Nomor 2 Tahun 2002 tentang Tata Cara Perlindungan Korban dan Saksi dalam Pelangaran HAM Berat disebutkan bahwa perlindungan terhadap saksi dan korban dapat dilakukan berdasarkan inisiatif aparat penegak hukum dan aparat keamanan, tetap saja akan lebih efektif apabila dengan adanya laporan polisi jenis $B$ berupa aduan atau pelaporan dari masyarakat tentang suatu tindak pidana pemerkosaan yang terjadi.

Berdasarkan data dari Badan Pusat Statistik terbaru, kejahatan di Indonesia rentang tahun 2016-2018 mengalami fluktuatif. Presentasi penduduk korban kejahatan mengalami penurunan dari 1,22 \% pada 2016 menjadi 1,08 \%. pada tahun 2017. Kemudian meningkat menjadi 1,11\% pada $2018 .^{10}$ Dari data ini menunjukan angka kriminalitas di Indonesia belum dapat dikendalikan dan cenderung fluktuatif.

\section{PENUTUP}

\section{A. Kesimpulan}

Tindak kejahatan pemerkosaan bukanlah kejahatan yang baru pada masa sekarang ini muncul, melainkan sudah ada sejak lama. Tindak pidana pemerkosaan terjadi tidak hanya di kota-kota, melainkan juga sampai perdesaan dimana pada dasarnya, nilai-

10

https://www.bps.go.id/Publication201 9/12/12/66c0114edb7517a33063871f/stati stik-kriminal-2019.html, diakses pada Selasa, 14 Januari 2020. 
Budi Heryanto dkk

Jurnal Hukum Mimbar Justitia

Vol. 6 No. 1 - Juni 2020

nilai sosial masih sangat dianut oleh masyarakat pedesaan.

Perempuan korban tindak pidana pemerkosaan adalah pihak yang dirugikan. Penderitaan mental dan psikis korban pemerkosaan dapat terjadi secara berkepanjangan. Apalagi jika korban pemerkosaan adalah anak di bawah umur, dimana pada usianya itu, seorang cenderung akan terpuruk mental dan kejiwaannya.

Tidak dapat dipungkiri, pelaku pada saat melakukan kejahatan, melakukan kekerasan terhadap fisik dan ancaman yang dilontarkan baik berupa ancaman akan diperkosa kembali hingga ancaman dibunuhnya korban.

Dalam melakukan pelaporan kepada aparat, korban yang mengalami sakit psikisnya seringkali merasa malu untuk melapor, dimana korban harus mengulang dan menceritakan kembali kejahatan yang menimpa korban. Selain itu, biaya yang dikeluarkan adalah murni dari korban pemerkosaan. Tidak jarang korban tidak melaporkan kejadian yang menimpanya karena pelaku dianggap masih ada hubungan keluarga, dimana melaporkan hanya akan membuat aib korban pemerkosaan menjadi bahan pembicaraan masyarakat. Namun, kesaksian yang dialami korbn dan/atau saksi kejahatan pemerkosaan sangat berperan dalam penegakan hukum.

\section{B. Saran}

Korban kejahatan pemerkosaan berperan dalam proses pengungkapan kejahatan pemerkosaan. Jaminan bagi saksi dan/atau korban kejahatan tindak pidana pemerkosaan mendapat perlindungan oleh aparat penegakan hukum. Peran keluarga dalam melakukan pengawasan dapat meminimalisir tingkat kejahatan pemerkosaan. Adapun jika kejahatan telah terjadi, keluarga korban harus dapat mengerti posisi korban dan harus dapat menerima korban dalam keluarga. Keluarga harus dapat menjadi pendamping korban pemerkosaan dalam menjalani rehabilitasi.

$$
\text { Selain keluarga, peran }
$$
masyarakat dalam menanggapi korban kejahatan tindak pemerkosaan menjadi penting. Masyarakat harus dapat berperan aktif menjaga perasaan 
Budi Heryanto dkk

Jurnal Hukum Mimbar Justitia

Vol. 6 No. 1 - Juni 2020

korban pemerkosaan, dimana korban pemerkosaan sedang sakit mental dan psikisnya. Pelabelan sudah semestinya tidak dilakukan untuk menghindari korban pemerkosaan menderita berkepanjangan. Masyarakat adalah lingkungan yang menjadi kunci dari tingkat kejahatan. Peningkatan kualitas spiritual masyarakat terhadap keimanan pada saat ini kurang dari seharusnya menyebabkan tingginya angka kejahatan di masyarakat. Hal ini dapat ditanggulangi dengan memperbaiki keimanan masyarakat dalam berkehidupan sosial.

\section{DAFTAR PUSTAKA}

\section{A. Buku.}

Bagong Suyanto dan Emy Susanti Hendrarso, 1996, Wanita Dari Subordinasi dan Marginalisasi Menuju ke Pemberdayaan, Airlangga University Press, Surabaya Barda Nawawi, 2002, Bunga Rampai Kebijakan Hukum Pidana, Citra Aditya Bakti, Bandung.

Leden Marpaung, 1996, Kejahatan Terhadap Kesusilaan Dan Masalah Prevensinya, Sinar Grafika, Jakarta.
Ronry Hanitidjo Soemitro, Metodologi Penelitian Hukum Dan Jurimetri, Ghalia Indonesia, Jakarta.

Soerjono Soekanto, 1986, Pengantar Penelitian Hukum, Universitas Indonesia, Jakarta.

B. Peraturan Perundang-Undangan.

Undang-Undang Dasar Negara Republik Indonesia Tahun 1945.

Undang-Undang Nomor 26 Tahun 2000 tentang Pengadilan Hak Asasi Manusia.

Undang-Undang Nomor 31 Tahun 2014 perubahan atas Undang-Undang Nomor 13 Tahun 2006 Tentang Perindungan Saksi dan Korban.

Peraturan Pemerintah Nomor 2 Tahun 2002 tentang Tata Cara Perlindungan Korban dan Saksi dalam Pelangaran HAM Berat.

\section{Jurnal, Skripsi, Tesis, Internet.}

Henny Nuraeny dan Tanti Kirana Utami, Pola Reintegrasi Sosial Korban Perdagangan Orang Di Kabupaten Cianjur Berbasis Pemberdayaan Ekonomi, Jurnal Hukum Mimbar Justitia, Fakultas Hukum Universitas Suryakancana, Cianjur. 
Budi Heryanto dkk

Jurnal Hukum Mimbar Justitia

Vol. 6 No. 1 - Juni 2020

Ira Dwiati, 2007, "Perlindungan Hukum Terhadap Korban Tindak Pidana Perkosaan Dalam Peradilan Pidana" Tesis, Fakultas Hukum, Universitas Diponogoro, Semarang.

Mia Amalia, 2016, Analisis Terhadap Tindak Pidana Prostitusi Dihubungkan Dengan Etika Moral Serta Upaya Penanggulangan Di Kawasan Cisarua Kampung Arab, Jurnal Mimbar Justitia Vol. II No. 02, Edisi Juli-Desember, Fakultas Hukum Universitas Surakancana, Cianjur.

Noptra, 2008, "Perlindungan Saksi Dan Korban Oleh Lembaga-Lembaga Negara Di Indonesia Sebelum Dan Sesudah Lahirnya UndangUndang Nomor 13 Tahun 2006 Tentang Perlindungan Saksi Dan Korban", Skripsi, Universitas Indonesia, Jakarta.

Statistik Kriminal 2019 Badan Pusat Statistik

https://www.bps.go.id/Publication2 019/12/12/66c0114edb7517a33063 871f/statistik-kriminal-2019.html diakses pada Selasa, 14 Januari 2020.

Trini Handayani, 2016, Perlindungan Penegakan Hukum Terhadap kasus Kekerasan Seksual Pada Anak, Jurnal Mimbar Justitia Vol. II No. 02, Edisi Juli-Desember, Fakultas Hukum Universitas Suryakancana, Cianjur.
Zuleha, 2015, Perlindungan Hukum Terhadap Anak Korban Pemerkosaan Dalam Perspektif Viktimologi, Jurnal Hukum Samudra Keadilan Vol. 10 No. 01, Edisi Januari-Juli, Fakultas Hukum Universitas Samudra, Aceh. 